\title{
PREMI RESTORNO DALAM PERJANJIAN ASURANSI
}

\author{
Marsidah \\ Fakultas Hukum Universitas Palembang \\ E-mail: marsidahelan.com
}

\begin{abstract}
$\overline{\text { Premium is one of the obligations of the insured that must be paid to the insurer, but the paid }}$ premium can be asked back by the insured. The premium that the insured party asks to return is called the Restorno Premium. The problems in this paper are the things that can lead to the Restorno Premium by the insurance agreement. Restorno Premium is the repayment of insurance premiums from the insurer to the insured due to the failure / cancellation of the insurance agreement from the insured who has good faith as stipulated in Article 281 of the KUHD. In addition, the Restorno Premium can be fulfilled by the insurer if there are things mentioned in Article 251 of the Criminal Code, namely false or untrue information or not telling things that the insured knows about.
\end{abstract}

Keywords: Restorno Premium

\begin{abstract}
Abstrak
Premi merupakan salah satu kewajiban dari pihak tertanggung yang harus dibayarkan kepada penanggung tetapi premi yang sudah dibayarkan tersebut dapat diminta kembali oleh tertanggung. Premi yang diminta kembali oleh pihak tertanggung di dalam asuransi disebut Premi Restorno. Untuk lebih jauh mengetahui Premi Restorno ini maka permasalahan dalam tulisan ini adalah hal-hal yang dapat menyebabkan terjadinya Premi Restorno oleh perjanjian asuransi. Berkaitan dengan permasalahan yang diteli bahwa Premi Restorno merupakan pembayaran kembali premi asuransi dari penanggung kepada tertanggung karena gugurnya/batalnya perjanjian asuransi dari tertanggung yang telah beritikad baik sebagaimana ditegaskan dalam Pasal 281 KUHD. Selain itu Premi Restorno dapat pula dipenuhi oleh pihak penanggung apabila terdapat hal-hal yang disebut dalam Pasal 251 KUHD, yaitu adanya keterangan yang keliru atau tidak benar atau tidak memberitahukan hal-hal yang diketahui oleh pihak tertanggung.
\end{abstract}

Kata Kunci: Premi Restorno

\section{PENDAHULUAN}

Kepemilikan benda atau barang yang dimiliki seseorang pasti akan memikirkan tentang jaminan terhadap kelangsungan kepemilikan barangbarang yang dimilikinya, yaitu dengan jalan mengalihkan risiko yang dapat terjadi pada barang-barang miliknya yang dapat dilakukan dengan cara mengasuransikan barang-barang atau benda-benda miliknya.

Seperti yang telah disebutkan di atas bahwa usaha si pemilik barang untuk berusaha mengalihkan kerugian yang terjadi, sehingga dengan adanya pengalihan kerugian tersebut menyebabkan si pemilik barang dapat terus bertahan atau dengan kata lain 
Marsidah, Premi Restorno dalam Perjanjian Asuransi, Halaman 312-321

peristiwa yang menyebabkan kerusakan atau kehilangan pada barangnya, tidak mempengaruhi usahanya. Pada dasarnya seorang pemilik suatu benda atau barang akan selalu menghadapi resiko terhadap apa yang dimilikinya. Penjabaran di atas dapat dilihat adanya dua pihak yang mengadakan perjanjian asuransi ini. Pihak pertama adalah pihak yang mengalihkan risiko atau kerugian yang dialaminya atau yang dihadapinya disebut tertanggung, sedangkan pihak kedua adalah pihak yang mau menerima pengalihan risiko disebut penanggung. Hubungan hukum antara pihak penanggung dengan pihak tertanggung diadakan dengan cara perjanjian antara kedua belah pihak.

Premi adalah pembayaran dari tertanggung kepada penanggung, sebagai imbalan jasa atas pengalihan risiko terhadap penanggung. ${ }^{1}$ Premi di dalam asuransi merupakan salah satu yang penting. Hal ini dapat dilihat dari ketentuan Pasal 246 Kitab UndangUndang Hukum Dagang (KUHD) yang menentukan bahwa :

"Asuransi atau pertanggungan adalah suatu perjanjian dengan nama seorang penanggung mengikatkan diri kepada tertanggung, dengan menerima suatu

1 Man Suparman Satrawidjaja, Aspek-Aspek Hukum Asuransi Dan Surat Berharga (Bandung: Penerbit P.T. Alumni, 2003). premi, untuk memberikan pergantian kepadanya karena suatu kerugian, kerusakan atau kehilangan yang diharapkan, yang mungkin akan dideritanya karena suatu peristiwa yang tak tertentu".

Dari pasal tersebut di atas jelaslah bahwa premi merupakan salah satu kewajiban dari pihak tertanggung yang harus dibayarkan kepada pihak penanggung. Di dalam praktik, ada kalanya premi yang dibayarkan kepada pihak penanggung (perusahaan asuransi) dapat diminta kembali oleh pihak tertanggung asalkan pihak tertanggung tersebut telah bertindak dengan itikad baik.

Premi yang diminta kembali oleh pihak tertanggung ini di dalam asuransi disebut dengan Premi Restorno. Premi Restorno ini telah diatur di dalam Kitab Undang-Undang Hukum Dagang (KUHD) Pasal 281 yang menyatakan : "Dalam segala hal dimana perjanjian pertanggungan itu untuk seluruhnya atau sebagian gugur atau menjadi batal, sedangkan si tertanggung tidak bertindak dengan itikad baik, maka si penanggung diwajibkan mengembalikan preminya untuk seluruhnya, ataupun untuk sebagian yang demikian untuk mana ia tidak telah menghadapi bahaya".

Melihat ketentuan Pasal 281 Kitab Undang-Undang Hukum Dagang 
Marsidah, Premi Restorno dalam Perjanjian Asuransi, Halaman 312-321

(KUHD) di atas yang hanya memberikan

batasan secara umum bahwa premi tersebut dapat diminta kembali asalkan tertanggung telah bertndak dengan itikad baik, maka tidak menutup kemungkinan akan menimbulkan perselisihan antar pihak tertanggung dan pihak penanggung karena sangat umumnya ketentuan batasan pasal tersebut.

Berdasarkan latar belakang di atas, maka permasalahan dalam tulisan ini adalah hal-hal apa saja yang dapat menyebabkan premi restorno dalam perjanjian asuransi. Permasalahan yang telah ditentukan dibahas dengan metode penelitian hukum normatif, dengan bahan hukum primer, sekunder dan tersier. Pendekatan yang digunakan adalah pendekatan Undang-Undang.

\section{PEMBAHASAN}

\section{A. Pengertian Premi Restorno}

Perjanjian antara pihak tertanggung dan pihak penanggung menimbulkan suatu hubungan hukum. Dengan adanya hubungan hukum tersebut maka pihak tertanggung dapat mengalihkan resiko yang akan dihadapinya kepada pihak penanggung, tetapi pihak tertanggung secara tersendirinya berkewajiban untuk membayar sejumlah uang yang disebut premi.
Premi ini biasanya dinyatakan dalam prosentase dari jumlah pertanggungan, yang menggambarkan penilaian penanggung terhadap resiko yang ditanggungnya, sehingga definisi premi adalah pembayaran dari tertanggung kepada penanggung, sebagai imbalan jasa atas pengalihan resiko kepada penanggung. Dalam teorinya memang mungkin premi ini ditiadakan berdasarkan persetujuan kedua belah pihak, kalau sama sekali tidak ada kerugian yang timbul. Tetapi pada praktiknya hal yang demikian itu tidak pernah terjadi, karena biasanya mesti ada atau tidaknya suatu kerugian yang timbul serta tidak jarangnya keseluruhan premi itu diasuransikan kembali (hervezekeren) kepada perusahaan asuransi premi. ${ }^{2}$

\section{Premi juga memiliki fungsi} memiliki fungsi untuk mengembalikan tertanggung pada posisi ekonomi seperti sebelum terjadinya kerugian dan untuk mengembalikan tertanggung dari kebangkrutan, hingga mampu berdiri pada posisi seperti keadaan sebelum terjadinya suatu kerugian. Dari fungsi premi tersebut dapat timbul faktor-faktor yang mempengaruhi penentuan tarif premi asuransi baik dari sisi eksternal

2 H.M.N. Purwosutjipto, Pengertian Pokok Hukum Dagang Indonesia VI: Hukum Pertanggungan (Jakarta: Djambatan, 2003). 
Marsidah, Premi Restorno dalam Perjanjian Asuransi, Halaman 312-321

maupun internal. Faktor yang mempengaruhi penentuan tarif premi asuransi dari sisi eksternal, yaitu persaingan, kondisi ekonomi dan peraturan perundang-undangan dari pemerintah. Sedangkan faktor yang mempengaruhi dari sisi internal obyek kerugian (terutama dalam asuransi kerugian), yaitu barang-barang yang diasuransikan, kondisi pertanggungan, alat pengukur barang yang diasuransikan, cara pengangkutan barang, jangka waktu pertanggungan.

Penentuan premi asuransi juga memiliki unsur-unsur, yaitu kemungkinan/probability terjadinya kerugian. Value judgement dan policy pemerintah. Premi asuransi juga memiliki komponen yaitu :

\section{Premi Dasar}

Yaitu premi yang dibebankan kepada tertanggung ketika polis dibuat dengan perhitungan data dan keterangan tertanggung serta luasnya resiko yang dijaminkan.

\section{Premi Tambahan}

Yaitu premi yang ditambahkan pada premi dasar ketika terjadi perubahan data dan keterangan tertanggung serta luasnya resiko yang dijaminkan.

3. Reduksi Tambahan
Yaitu potongan premi yang disebabkan keadaan tertentu seperti, pembayarn premi sekaligus untuk beberapa tahun, pembayaran premi melalui lembaga keuangan tertentu.

4. Tarif Kompeni

Yaitu besarnya tarif yang ditentukan oleh asosiasi perusahaan guna menghindari persaingan yang tidak sehat.

Menurut Pasal 1266 ayat 1-4 KUHPerdata : "Syarat batal dianggap selalu dicantumkan dalam persetujuanpersetujuan yang bertimbal balik, manakala salah satu pihak tidak memenuhi kewajibannya. Dalam hal demikian, persetujuan tidak batal demi hukum tetapi pembatalan harus dimintakan kepada hakim.

Mengenai saat pembayaran premi, bukan merupakan hal yang penting. Biasanya premi dibayar dengan tunai pada saat perjanjian asuransi atau pertanggungan itu ditutup. Tetapi apabila premi itu diperjanjikan dengan angsuran, maka premi itu dibayar pada permulaan tiap-tiap waktu angsuran. Perincian yang dapat dikalkulasikan dalam jumlah premi itu adalah :

1. Jumlah presentase dar jumlah yang dipertanggungkan. 
Marsidah, Premi Restorno dalam Perjanjian Asuransi, Halaman 312-321

2. Jumlah biaya-biaya yang dikeluarkan oleh penanggung misalnya biaya meterai, biaya polis.

3. Kurtasi untuk perantara apabila pertanggungan diadakan lewat perantara.

4. Keuntungan bagi penanggung dan jumlah cadangan. ${ }^{3}$

Premi merupakan salah satu kewajiban dari pihak tertanggung yang harus dibayarkan kepada penanggung. Premi yang diminta kembali oleh pihak tertanggung ini di dalam asuransi disebut dengan Premi Restorno.

Premi Restorno ini telah diatur di dalam Kitab Undang-Undang Hukum Dagang (KUHD) Pasal 281 yang menyatakan :

"Dalam segala hal dimana perjanjian pertanggungan itu untuk seluruhnya atau sebagian gugur atau menjadi batal, sedangkan si tertanggung telah bertindak dengan itikad baik, maka si penanggung diwajibkan mengembalikan preminya untuk seluruhnya, ataupun untuk sebagian yang demikian untuk mana ia tidak telah menghadapi bahaya".

Dari uraian di atas, maka dapat disimpulkan bahwa premi restorno adalah pembayaran kembali premi asuransi dari penanggung (Perusahaan Asuransi) kepada tertanggung karena gugurnya atau batalnya perjanjian dan tertanggung dalam hal ini telah bertindak

3 Abdulkadir Muhammad, Hukum Asuransi Indonesia (Bandung: PT Citra Aditya, 2006). dengan itikad baik (te goder grow in good faith). ${ }^{4}$

Mengenai pengertian premi restorno di atas, maka pengaturan pengaturan premi restorno dengan secara tidak langsung telah diatur secara hukum. Di dalam Kitab Undang-Undang Hukum Dagang (KUHD), masalah premi restorno ini diatur dalam beberapa pasal, yaitu Pasal 281, 282, 635, 636, dan Pasal 662. Sedangkan dalam Kitab UndangUndang Hukum Perdata (KUHPerdata), masalah premi restorno juga diatur dalam Pasal 1359, 1452, dan Pasal 1453 KUHPerdata.

Pelaksanaan premi restorno menimbulkan tujuan baik bagi penanggung maupun bagi tertanggung. Tujuan premi restorno yaitu untuk memenuhi asas: keseimbangan dan keadilan. $^{5}$ Dengan masa asas perseimbangan, merupakan asas yang penting, karena resiko yang diperalihkan kepada penanggung itu diimbangkan dengan jumlah premi yang dibayar oleh tertanggung.

Asas perseimbangan dan asas keadilan berpengaruh dalam memenuhi tujuan dari premi restorno. Asas-asas tersebut bertujuan untuk mencegah

4 Abdulkadir Muhammad, Pokok-pokok Hukum Pertanggungan, Cetakan Pertama (Bandung: Alumni, 1983).

${ }^{5}$ Abdulkadir Muhammad 
Marsidah, Premi Restorno dalam Perjanjian Asuransi, Halaman 312-321

orang yang ingin berspekulasi mencari keuntungan, yang tidak halal dengan mengadakan berkali-kali pertanggungan guna untuk mendapatkan ganti rugi yang berlebihan, sehingga dalam pelaksanaannya, premi akan dikembalikan atau dapat diminta kembali apabila tertanggung telah beritikad baik.

\section{B. Hal-Hal yang Menyebabkan Terjadinya Premi Restorno Dalam Perjanjian Asuransi}

Seperti yang telah dijelaskan sebelumnya, bahwa premi restorno merupakan pengembalian premi yang telah dibayarkan harus oleh tertanggung kepada penanggung atas suatu nilai pertanggungan untuk perlindungan kepentingan atau asset milik tertanggung karena kepentingan atau asset tersebut misalnya telah dijual atau tidak lagi menjadi milik tertanggung. Pengembalian premi ini dalam istilah asuransinya dinamakan. Berdasarkan wawancara dengan Rusdi (Wakil Kepala PT Parolamas Cabang Palembang) menyatakan bahwa, proses Endoserment/Perubahan merupakan proses pengembalian premi ini baru dapat dilakukan bila tertanggung memenuhi salah satu prinsip dasar dari asuransi yaitu harus mempunyai itikad baik atas pembatalan tersebut.

Pelaksanaan premi restorno itu sendiri suatu tujuan baik bagi penanggung maupun tertanggung. Tujuan diadakannya premi restorno itu sendiri adalah mengantisipasi spekulasi yang mungkin dilakukan oleh tertanggung dengan cara mengasuransikan objek pertanggungan dilebihi dari satu perusahaan asuransi dengan maksud memperoleh keuntungan dengan mendapatkan pergantian lebih dari satu perusahaan asuransi. Sebagaimana kita ketahui bahwa di dalam asuransi kerugian, hal ini juga akan merugikan tertanggung dalam pembayaran preminya dan jika terjadi klaim penggantiannya tidak melebihi nilai terhadap objek pertanggungan sesaat sebelum kerugian (sesuai dengan principles of indemnity) dan di beberapa perusahaan asuransi yang mengcover objek pertanggungan tersebut akan berbagi untuk membayar ganti rugi. Dalam pelaksanaannya premi restorno itu sendiri bertujuan untuk memenuhi hal-hal sebagai berikut :

\section{Dasar Pertimbangan Premi}

Premi yang dibayar oleh tertanggung ditimbangi dengan peralihan resiko kepada penanggung walaupun besarnya premi tersebut tidak mungkin 
Marsidah, Premi Restorno dalam Perjanjian Asuransi, Halaman 312-321

seimbang dengan resiko yang akan ditanggung oleh penanggung, namun pihak-pihak yang terlibat dalam perjanjian asuransi tersebut harus bertindak saling memenuhi satu sama lain.

\section{Dasar Keadilan Perjanjian}

Merupakan pendukung dari dasar pertimbangan premi dimana antara kedua belah pihak mendapat hak dan kewajiban secara adil untuk menghindari perselisihan antara tertanggung dengan penanggung dalam melakukan perjanjian asuransi tersebut.

Dalam mencari pengertian dari pertanggungan batal atau pertanggungan gugur atau yang berhubungan dengan pengertian itu, pemerintah telah menetapkan dasar hukum yang berhubungan dengan premi restorno tersebut baik yang diatur dalam Kitab Undang-Undang Hukum Dagang (KUHD) maupun Kitab Undang-Undang Hukum Perdata (KUHPerdata).

Pasal-pasal yang terdapat dalam KUHD antara lain adalah 251 KUHD disebutkan bahwa: "Batalnya pertanggungan dapat disebabkan oleh keterangan yang keliru atau tidak memberitahukan hal-hal yang diketahui oleh si tertanggung".
Selanjutnya pada Pasal 276 dikatakan bahwa "si penanggung tidak akan bertanggung jawab apabila ia sudah mulai memikul sesuatu bahaya, jika kerusakan atau kerugian yang terjadi disebabkan oleh kesalahan tertanggung". Dan juga dalam Pasal 294 dikatakan hal yang sama. Pasal-pasal yang disebutkan di atas saling berkaitan satu sama lain, ada pasal yang memberikan pengertian pertanggungan batal atau pertanggungan gugur, juga ada pasal yang memberikan syarat untuk terjadinya pertanggungan batal atau pertanggungan gugur.

Dalam KUHPerdata juga mengatur masalah batalnya suatu perjanjian, yaitu Pasal 1359 yang menyatakan bahwa tiap-tiap pembayaran memperkirakan adanya suatu hutang apa yang telah dibayarkan dengan tidak diwajibkan, dapat dituntut kembali. Terhadap perikatan-perikatan bebas, yang secara sukarela telah dipenuhi tidak dapat melakukan penuntutan kembali. Dari kutipan Pasal 1359 KUHPerdata maka dapat di implementasi ke asuransi sehingga dapat dinyatakan bahwa jika perjanjian batal, maka uang premi tidak perlu dibayar dan kalau sudah mengenai pengembalian premi dalam hal batalnya perjanjian pertanggungan dan gugurnya 
Marsidah, Premi Restorno dalam Perjanjian Asuransi, Halaman 312-321

pertanggungan digunakan pasal-pasa yang ada dalam KUHD.

Disamping itikad baik yang harus ada pada tertanggung, syarat-syarat lain yang harus dipenuhi untuk dapat terjadinya premi restorno adalah si penanggung tidak telah menghadapi bahaya dan juga hal yang menyebabkan gugurnya atau batalnya pertanggungan itu bukan karena kesalahan si tertanggung.

Di dalam praktek, disamping menurut ketentuan-ketentuan di atas, ada hal-hal lain yang juga menyebabkan pertanggungan yang sudah berjalan itu diminta dihentikan baik itu oleh tertanggung maupun oleh penanggung antara lain adalah :

1. Perpindahan tangan atas pertanggungan

Contoh pada asuransi kendaraan bermotor (mobil).

Tertanggung bisa meminta penanggung untuk membatalkan asuransi atas mobilnya dan meminta pengembalian premi atas batalnya asuransi tersebut dari sejak mobilnya dipindahtangankan atau dijual kepada orang lain. Tertanggung juga bisa meminta asuransi atas mobilnya tidak dibatalkan tetapi cukup diganti nama tertanggungnya sepanjang penggantian tersebut disetujui dari penanggung.

2. Perubahan penggunaan objek pertanggungan baik dari objek pertanggungan itu sendiri maupun dari lingkungan sekitar objek pertanggungan. Contoh, asuransi kebakaran. Tertanggung harus melaporkan sesegera mungkin perubahan terlanjur dibayar dapat diminta kembali. Bahkan Pasal 1452 dan Pasal 1453 KUHPerdata menyatakan bahwa kebatalan tersebut dapat disebabkan oleh adanya paksaan, kekeliruan atau penipuan yang menyebabkan semua yang telah terjadi selama ini harus dipulihkan kembali seperti semula, kecuali penggantian bunga dan biaya-biaya, jika ada alasannya untuk itu.

Pasal-pasal yang disebutkan dalam KUHPerdata tersebut merupakan peraturan yang memberatkan penanggung, karena tertanggung dengan itikad jahatnya dapat menipu penanggung untuk merugikannya jika hal ini terjadi atau penanggung mengetahuinya maka perjanjian atau pertanggungan itu menjadi batal, dan jika pertanggungan itu batal, maka segala hal harus dipulihkan sebagaimana semula, jadi dalam hal adanya penipuan pun, keadaan harus dikembalikan sebagaimana semula. Sedangkan jika itikad jahat itu tidak diketahui, maka penanggung dapat dirugikan. Oleh karena itu, bagi perjanjian pertanggungan diadakan peraturan khusus masalah premi ini, yaitu dalam pasal-pasal yang disebutkan di atas. Pada 
Marsidah, Premi Restorno dalam Perjanjian Asuransi, Halaman 312-321

intinya, ketentuan tersebut berarti premi dapat dikembalikan jika tertanggung beritikad baik, sebaliknya premi tidak dapat diminta kembali jika si tertanggung tidak beritikad baik.

Ketentuan pemakaian peraturan antara KUHPerdata dan KUHD dapat didasarkan atas adagium "Lex specialist derogarthlex generalis" yang berarti hukum khusus yang menghapuskan hukum umum. Jadi dalam masalah ini yaitu penggunaan atas bangunan pada saat awal penutupan asuransi misalnya rumah tinggal tersebut penggunaannya berubah menjadi gudang atau bagian depannya dibuat warung atau bangunan milik orang lain di sebelahnya menjadi gudang/warung/toko dimana tertanggung akan menambah premi pada masa asuransi masih berjalan sampai dengan jatuh tempo seiring dengan meningkatnya resiko akibat perubahan atas objek pertanggungan tersebut. Tertanggung bisa membatalkan asuransi ini dengan mendapatkan pengembalian premi atas sisa masa pertanggungan sejak perubahan objek pertanggungan.

KUHD sebenarnya tidak menyebutkan secara tegas dan jelas halhal yang dapat menyebabkan terjadinya penghentian pertanggungan tersebut yang dapat menyebabkan dikembalikannya premi yang telah dibayar. Salah satu yang dapat kita ambil dari praktek adalah masalah pemberatan resiko. Jika terjadi pemberatan resiko terhadap objek pertanggungan maka tertanggung harus dengan segera memberitahukan kepada penanggung. Penanggung berhak menentukan, pertanggungan itu diteruskan dengan premi yang sudah ada atau dengan premi yang tinggi, atau dihentikan sama sekali. Jika tidak terjadi kecocokan antara penanggung dengan tertanggung, maka premi yang sudah dibayar untuk jangka waktu yang belum habis dikembalikan kepada tertanggung.

Dari penjabaran tersebut jika terjadi dalam asuransi kebakaran yang mana apabila sebuah rumah diasuransikan oleh pemiliknya terhadap bahaya kebakaran dan apabila pada waktu perjanjian pertanggungan tersebut dibuat atau ditutup dengan keadaan lingkungan di sekitar rumah tersebut baik dalam arti tidak ada bangunan dan barang yang dapat mempermudah terjadinya kebakaran. Setelah beberapa waktu berjalan, lingkungan di sekitar rumah tersebut berubah, menjadi ada bangunan dan barang yang dapat membuat besar kemungkinan tersebut kebakaran. Keadaan tersebut dapat 
Marsidah, Premi Restorno dalam Perjanjian Asuransi, Halaman 312-321

merugikan penanggung biasanya dalam Pasal 281 KUHD. Selain itu penanggung akan meminta premi premi restorno dapat pula dipenuhi oleh pertanggungan dinaikkan atau jika tidak pertanggungan akan dihentikan saja. Jika penghentian pertanggungan itu terjadi maka akan timbul premi restorno.

Apabila dikaitkan antara ketentuan yang ada dengan apa yang ada di dalam praktiknya, pada asuransi kebakaran bisa terjadi penyampingan dari syarat yang harus dipenuhi untuk dapat terjadinya premi restorno, contohnya yaitu para pihak dapat meminta penghentian pertanggungan yang sedang berjalan tanpa diwajibkan memberitahukan sebabnya, dengan kata lain jika pertanggungan sudah berjalan penanggung telah mulai menghadapi bahaya, tetapi dalam hal ini para pihak baik penanggung maupun tertanggung dapat meminta pertanggungan itu dihentikan.

\section{KESIMPULAN DAN REKOMENDASI}

Premi restorno adalah pembayaran kembali premi asuransi dari penanggung (perusahaan asuransi) kepada tertanggung karena gugurnya/batalnya perjanjian asuransi dan tertanggung dalam hal ini telah bertindak dengan itikad baik, sebagaimana ditegaskan pihak penanggung apabila terdapat halhal yang disebutkan dalam Pasal 251 KUHD, yaitu adanya keterangan yang keliru atau tidak benar atau tidak memberitahukan hal-hal yang diketahui oleh pihak tertanggung.

Dapat disarankan kepada pemerintah bahwa sudah saatnya Pemerintah mengeluarkan ketentuan yang baru mengenai perasuransian. Serta dalam membuat suatu peraturan tersebut hendaklah klausula-klausula yang ada dalam polis yang dikeluarkan oleh perusahaan-perusahaan asuransi dapat dijadikan acuan dalam pembuatan peraturan tersebut.

\section{DAFTAR PUSTAKA}

Abdulkadir Muhammad, Hukum Asuransi Indonesia. Bandung: PT Citra Aditya, 2006.

Abdulkadir Muhammad, Pokok-pokok Hukum Pertanggungan, Cetakan Pertama. Bandung: Alumni, 1983.

H.M.N. Purwosutjipto, Pengertian Pokok Hukum Dagang Indonesia VI: Hukum Pertanggungan. Jakarta: Djambatan, 2003.

Man Suparman Satrawidjaja, AspekAspek Hukum Asuransi Dan Surat Berharga. Bandung: Penerbit P.T. Alumni, 2003. 